\title{
Effect of Spirulina (Arthrospira plantensis) Supplementation on Wool Quality in Purebred and Crossbred Merino Lambs Fed Pasture and Lucerne Hay Basal Diets
}

\author{
B. W. B. Holman ${ }^{1} \&$ A. E. O. Malau-Aduli ${ }^{2,3}$ \\ ${ }^{1}$ New South Wales Department of Primary Industries, Centre for Red Meat and Sheep Development, Cowra, New \\ South Wales 2794, Australia \\ ${ }^{2}$ Animal Science and Genetics, Tasmanian Institute of Agriculture, School of Land and Food, Faculty of Science, \\ Engineering \& Technology, University of Tasmania, Sandy Bay, Hobart Tasmania 7001, Australia \\ ${ }^{3}$ School of Veterinary and Biomedical Sciences, Faculty of Medicine, Health and Molecular Sciences, James \\ Cook University, Townsville Queensland 4811, Australia \\ Correspondence: A. E. O. Malau-Aduli, Animal Science and Genetics, Tasmanian Institute of Agriculture, School \\ of Land and Food, Faculty of Science, Engineering and Technology, University of Tasmania, Sandy Bay, Hobart \\ Tasmania 7001, Australia; School of Veterinary and Biomedical Sciences, Faculty of Medicine, Health and \\ Molecular Sciences, James Cook University, Townsville Queensland 4811, Australia. Email: \\ Aduli.MalauAduli@utas.edu.au; aduli.malauaduli@jcu.edu.au
}

Received: March 24, 2014 Accepted: May 8, 2014 Online Published: June 15, 2014

doi:10.5539/jas.v6n7p120 URL: http://dx.doi.org/10.5539/jas.v6n7p120

\begin{abstract}
This study investigated the effects of Spirulina (Arthrospira plantensis) supplementation level, basal diet, sire breed, and sex on wool quality parameters in purebred and crossbred Merino lambs. A total of 48 lambs, over two consecutive years $(\mathrm{n}=24$ per year), was randomly allocated into Spirulina supplementation level (CONTROL, LOW, MEDIUM, HIGH) groups and balanced by sire breed (Black Suffolk, Dorset, Merino, White Suffolk) and sex (ewes, wethers). Lambs had ad libitum access to a basal diet of pasture and Lucerne hay, and had Spirulina supplement daily throughout the 42-day feeding trial, after a 21-day adjustment phase. Mid-side wool samples were removed from each lamb at the beginning and end of the feeding trial and commercially analysed for quality. The wool quality data were transformed into 'wool trait change over the feeding trial period' by the difference between the wool measurements at the beginning and end of the experiment prior to statistical analysis. Wool clean fleece weight (CFW) was significantly influenced by level of supplementation, basal diet and sex $(P<0.05)$. Spirulina-supplemented lambs on Lucerne hay basal diet elicited higher CFW responses which increased with supplementation level. CONTROL lambs had the lightest CFW regardless of basal diet. Sire breed and sex variations were significant $(P<0.05)$ as wool from Suffolk-sired lambs and ewes had the highest fibre diameter coefficient of variation (CV) and CFW, respectively. CV and fibre diameter standard deviation were the most affected wool traits by significant interactions between Spirulina supplementation level, sire breed and sex. It was concluded that Spirulina supplementation with Lucerne hay basal diet improves wool CFW without compromising wool fibre diameter, comfort factor and spinning fineness in dual-purpose prime lambs.
\end{abstract}

Keywords: wool quality, Spirulina, purebred, crossbred Merinos, pasture-fed

\section{Introduction}

Spirulina (Arthrospira platensis) is a highly nutritious, protein-rich and edible cyanobacterium. A review of literature on its use as a supplementary livestock feed has been published (Holman \& Malau-Aduli, 2012b). However, to the best of our current knowledge, research into Spirulina's potential for supplementing dual-purpose prime lambs where wool and meat production are of immense economic interests, remains scarce. Apart from the influence of Spirulina on growth and body conformation traits (Holman, Kashani, \& Malau-Aduli, 2012), there is no published literature on Spirulina's impact on wool quality traits in prime lambs, thus creating a knowledge gap that needs to be filled.

The sheep industry's use of crossbreeding and protein-rich supplements in dual-purpose prime lamb operations as tools to boost lamb growth rates and liveweight gains (ABARE., 2012) could potentially be complimented by 
Spirulina's protein-rich nature. This is as the availability of many traditional supplements is projected to decline in the short to medium-term due to increasing competition from other sectors such as biofuels, consumables, urban sprawl, land encroachment and climatic events (Harle, Howden, Hunt, \& Dunlop, 2007; Nardone, Ronchi, Lacetera, Ranieri, \& Bernabucci, 2010). Therefore, alternative protein-rich supplements such as Spirulina, are essential to future industry stability and development (Hume, Whitelaw, \& Archibald, 2011).

Apart from meat production, dual-purpose lamb operations derive a significant proportion of their economic returns from wool production. However, crossbreeding and supplementation with traditional protein-rich sources such as grains and canola, have been associated with lesser wool quality (Malau-Aduli \& Akuoch, 2012; Masters, Mata, \& Liu, 1999). Wool quality traits are objectively assessed routinely in the Australian sheep industry because of links to intrinsic economic value and textile manufacturing performances (Holman \& Malau-Aduli, 2012a). However, these traits can be influenced by crossbreeding, type and level of protein-rich supplementation, lamb sire breed, sex and basal diet. Hence, the impact of these factors on wool quality must be included in any research investigation into alternative protein-rich sources of dietary supplementation in prime lambs.

Our aim was to evaluate the effect of Spirulina supplementation and its interactions with sire breed, sex and basal diet on wool quality in purebred and crossbred Merino lambs under typical pasture-based and simulated drought conditions over two consecutive years. We hypothesised that Spirulina supplementation will improve wool yield without compromising wool quality in dual-purpose prime lambs.

\section{Method}

This experiment was carried out at the University of Tasmania (UTAS) Farm, Cambridge, Hobart, Tasmania, Australia, in accordance with the 1993 Tasmanian Animal Welfare Act and the 2004 Australian Code of Practice for the Care and Use of Animals for Scientific Purposes and approved by the UTAS Animal Ethics Committee.

\subsection{Animals}

Over two consecutive years, a mating ratio of 1 terminal ram to 100 Merino ewes was used to produce $F_{1}$ crossbred progeny sired by Dorset, Suffolk and Merino rams. At 12 weeks of age, all progeny were identified using National Livestock Identification ear tags and weaned onto ryegrass pastures. At 6 months of age, a total of 48 lambs (average body weight of $27 \mathrm{~kg}$ ) was randomly selected for both feeding trials; 24 lambs (12 ewes and 12 wethers) on ryegrass pasture basal diet (Year 1); and, 24 lambs (12 ewes and 12 wethers) on Lucerne hay basal diet (Year 2) on the same property and under the same management conditions. Each feeding trial continued for 9 weeks after three weeks of adjustment, during which commercially purchased Spirulina powder (TAAU, Darwin, Northern Territory, AUS) was directly supplemented to lambs by oral drenching daily in a water suspension at a Spirulina (g) : Water $(\mathrm{mL})$ ratio of $1: 10 \mathrm{w} / \mathrm{v}$.

Pasture-fed: Random lamb allocation into the following treatment groups was undertaken: CONTROL $(0 \mathrm{~mL})$, MEDIUM (100 mL) and HIGH (200 mL) Spirulina supplementation levels balanced by lamb sire breed (Black Suffolk, Dorset, Merino and White Suffolk) and sex (ewes and wethers). All lambs had ad libitum access to drinking water, $150 \mathrm{~g}$ of barley grains per day and were run as a single flock on ryegrass pasture.

Lucerne Hay: Treatment groups of Spirulina supplementation levels were: CONTROL (0 mL), LOW (50 mL), MEDIUM (100 mL), and HIGH $(200 \mathrm{~mL})$; sire breeds - Dorset, Merino and White Suffolk; and sex - ewes and wethers. Lambs were confined in individual $0.6 \mathrm{~m} \times 1.2 \mathrm{~m}$ metabolic crates with ad libitum access to drinking water and Lucerne hay, which was replaced daily. All lambs received barley (150 g/day).

\subsection{Wool Analysis}

Midside wool samples of approximately $10 \mathrm{~cm}^{2}$ were shorn using Oster-Sunbeam electric shears, from the same location on each lamb at the commencement and completion of each feeding trial as per Baxter and Cottle (1998). These samples were accurately catalogued and analysed using the Sirolan Laserscan ${ }^{\mathrm{TM}}$ (CSIRO, Melbourne, AUS) at the Australian Wool Testing Authority (AWTA, Melbourne AUS) for clean fleece yield (YIELD), mean fibre diameter (FD), coefficient of fibre diameter variation (CV), fibre diameter standard deviation (SD), comfort factor (CF), fibre curvature (CURV) and spinning fineness (SF).

\subsection{Chemical Analysis of Spirulina and Basal Diet Components}

Dry matter content of Spirulina and the basal diets was determined by drying samples to a constant weight at $65^{\circ} \mathrm{C}$ in a fan forced oven. Ash content was determined by combusting samples in a furnace at $550{ }^{\circ} \mathrm{C}$ for 5 hours. Neutral detergent fibre and acid detergent fibre contents were measured using an Ankom fibre analyser (ANKOM220; Ankom Technology USA) (van Soest, Roberts, \& Lewis, 1991). Total N content was measured using the Kjeldahl method (van Soest et al., 1991)and multiplied by 6.25 to find crude protein values. Ether extract 
was determined using Soxhlet methodology of fat extraction while in vitro digestibility and metabolisable energy was estimated using near infrared reflectance spectroscopy (Garnsworthy \& Unal, 2004).

Table 1. Nutrient composition of Spirulina and basal diet of ryegrass pasture and barley grain

\begin{tabular}{|c|c|c|c|c|c|}
\hline \multirow{2}{*}{ Chemical composition } & \multicolumn{4}{|c|}{ Feed components } & \multirow{2}{*}{ Unit } \\
\hline & Spirulina & Barley grain & Ryegrass pasture & Lucerne hay & \\
\hline $\mathrm{DM}$ & 96.0 & 93.2 & 44.7 & 90.6 & $\mathrm{~g} / 100 \mathrm{~g}$ Fresh Wt \\
\hline NDF & 32.6 & 18.5 & 22.4 & 36.0 & $\mathrm{~g} / 100 \mathrm{~g} \mathrm{DM}$ \\
\hline NDFn & 30.3 & 17.2 & 20.8 & 33.5 & $\mathrm{~g} / 100 \mathrm{~g} \mathrm{DM}$ \\
\hline $\mathrm{ADF}$ & 18.3 & 6.0 & 23.0 & 29.0 & $\mathrm{~g} / 100 \mathrm{~g} \mathrm{DM}$ \\
\hline NFC & 7.9 & 68.7 & 43.5 & 35.2 & $\mathrm{~g} / 100 \mathrm{~g} \mathrm{DM}$ \\
\hline Ash & 9.5 & 3.2 & 11.9 & 6.9 & $\mathrm{~g} / 100 \mathrm{~g} \mathrm{DM}$ \\
\hline EE & 5.9 & 2.0 & 3.0 & 1.9 & $\mathrm{~g} / 100 \mathrm{~g} \mathrm{DM}$ \\
\hline $\mathrm{CP}$ & 62.2 & 8.9 & 20.8 & 22.5 & $\mathrm{~g} / 100 \mathrm{~g} \mathrm{DM}$ \\
\hline ME & 1707.5 & 1723.7 & 1701.1 & 564.3 & $\mathrm{~kJ} / 100 \mathrm{~g} \mathrm{DM}$ \\
\hline
\end{tabular}

Dry matter (DM), neutral detergent fibre (NDF), nitrogen free NDF (NDFn), non-fibrous carbohydrate (NFC) as $100-(\mathrm{NDFn}+\mathrm{CP}+\mathrm{EE}+\mathrm{Ash})$, acid detergent fibre (ADF), ether extract (EE), crude protein $(\mathrm{CP})$, and metabolisable energy (ME).

\subsection{Statistical Analysis}

Prior to analysis, all data were transformed to assess the change in wool traits over the duration of the feeding trial by computing the difference between the initial and final values for each of the wool quality traits. The Statistical Analysis System software package (SAS, 2009) was utilised to compute unadjusted means, standard deviations, minimum, maximum values and a range of summary statistics that were carefully examined for any data entry errors or outliers. PROC REG (SAS, 2009) was utilised in testing linear, cubic and quadratic orthogonal contrasts prior to running a repeated measures ANOVA using general linear models (PROC GLM) fitting Spirulina supplementation level, year, sire breed, sex, basal diet and their interactions as fixed effects in the model and wool traits as dependent variables. Year and some second order interactions were removed from the final model because they were not significant sources of variation. Tukey's pairwise comparison tests were used to separate means at the $P<0.05$ threshold of statistical significance. The final statistical model used for the analysis was:

$$
\mathrm{Y}_{\mathrm{ijklm}}=\mu+\mathrm{SB}_{\mathrm{i}}+\mathrm{L}_{\mathrm{j}}+\mathrm{S}_{\mathrm{k}}+\mathrm{B}_{1}+(\mathrm{SBL})_{\mathrm{ij}}+(\mathrm{SBS})_{\mathrm{ik}}+(\mathrm{SBB})_{\mathrm{il}}+(\mathrm{LS})_{\mathrm{ik}}+(\mathrm{LB})_{\mathrm{il}}+(\mathrm{SB})_{\mathrm{kl}}+\mathrm{e}_{\mathrm{ijklm}}
$$

where $\mathrm{Y}=$ dependent variable, $\mu=$ overall mean, $\mathrm{SB}=$ sire breed, $\mathrm{L}=$ level of supplementation, $\mathrm{S}=$ sex, brackets represent second-order interactions and $\mathrm{e}=$ error.

\section{Results}

Lambs in the HIGH and LOW Spirulina supplementation levels had higher wool CFW than CONTROL lambs and ewe lambs recorded the highest CFW (Table 2). Lambs fed Lucerne hay basal diet had higher wool CFW than their pasture-fed counterparts. Black Suffolk-sired lambs had the highest CV compared with other sire breeds. No other independent effects on wool quality traits were found $(P>0.05$; Table 2$)$.

However, there were significant sire breed, supplementation level and sex interactions that influenced wool quality traits (Figures 1-3). At LOW levels of Spirulina supplementation, the wool CV of White Suffolk-sired lambs was lower than that of CONTROL (unsupplemented) lambs (Figure 1). Wether lambs receiving MEDIUM levels of Spirulina supplementation had higher CV than lambs supplemented at LOW Spirulina levels (Figure 2). Dorset-sired lambs had the highest SD, followed sequentially by White Suffolk- and Merino-sired lambs on Lucerne hay basal diet, but on pasture-fed basal diet, Black Suffolk-sired lambs had higher SD than Dorset-sired lambs (Figure 3a). Other significant second order interactions were observed in which pasture-fed Dorset-sired lambs had the highest CV in comparison with lambs on Lucerne hay basal diet. When lambs pasture-fed, it was observed that the CV of Black Suffolk-sired lambs were higher than that of Dorset-sired lambs (Figure 3b). 
Table 2. Least squares means (standard error) of clean fleece weight (CFW), mean fibre diameter (FD), fibre diameter standard deviation (SD), fibre diameter coefficient of variation (CV), comfort factor (CF), spinning fineness (SF), and fibre curvature (CURV) as affected by Spirulina supplementation level, sire breed, sex and basal diet

\begin{tabular}{|c|c|c|c|c|c|c|c|c|}
\hline & & \multicolumn{7}{|c|}{ Wool Quality Trait } \\
\hline & & CFW (\%) & $\mathrm{FD}(\mu \mathrm{m})$ & CV (\%) & SD & CF (\%) & $\begin{array}{l}\text { CURV } \\
(\% / \mathrm{mm})\end{array}$ & $\mathrm{SF}(\mu \mathrm{m})$ \\
\hline \multirow[t]{6}{*}{ Spirulina } & CONTROL & $\begin{array}{l}-2.84^{\mathrm{C}} \\
(1.37)\end{array}$ & $\begin{array}{l}0.41 \\
(1.06)\end{array}$ & $\begin{array}{l}1.09 \\
(0.98)\end{array}$ & $\begin{array}{l}0.34 \\
(0.26)\end{array}$ & $\begin{array}{l}-4.75 \\
(3.25)\end{array}$ & $\begin{array}{l}-3.57 \\
(2.52)\end{array}$ & $\begin{array}{l}1.44 \\
(0.90)\end{array}$ \\
\hline & LOW & $\begin{array}{l}2.35^{\mathrm{A}^{\prime}} \\
(1.23)\end{array}$ & $\begin{array}{l}1.57 \\
(0.47)\end{array}$ & $\begin{array}{l}-0.97 \\
(0.72)\end{array}$ & $\begin{array}{l}0.07 \\
(0.15)\end{array}$ & $\begin{array}{l}-3.85 \\
(2.21)\end{array}$ & $\begin{array}{l}-1.83 \\
(3.23)\end{array}$ & $\begin{array}{l}1.35 \\
(0.38)\end{array}$ \\
\hline & MEDIUM & $\begin{array}{l}-1.51^{\mathrm{BC}} \\
(1.54)\end{array}$ & $\begin{array}{l}0.61 \\
(0.40)\end{array}$ & $\begin{array}{l}0.55 \\
(0.55)\end{array}$ & $\begin{array}{l}0.23 \\
(0.12)\end{array}$ & $\begin{array}{l}-4.29 \\
(2.19)\end{array}$ & $\begin{array}{l}-2.21 \\
(240)\end{array}$ & $\begin{array}{l}0.70 \\
(036)\end{array}$ \\
\hline & & $0.74^{\mathrm{AB}}$ & 0.33 & -0.11 & 0.06 & -2.46 & -5.00 & 0.34 \\
\hline & HIGH & $(1.17)$ & $(0.48)$ & $(0.76)$ & $(0.16)$ & $(1.85)$ & $(2.67)$ & $(0.40)$ \\
\hline & $P$ & 0.020 & 0.708 & 0.674 & 0.868 & 0.848 & 0.919 & 0.494 \\
\hline \multirow[t]{5}{*}{$\begin{array}{l}\text { Sire } \\
\text { breed }\end{array}$} & $\begin{array}{l}\text { Black } \\
\text { Suffolk }\end{array}$ & $\begin{array}{l}-3.07 \\
(1.82)\end{array}$ & $\begin{array}{l}-0.70 \\
(0.91)\end{array}$ & $\begin{array}{l}3.03^{\mathrm{A}^{2}} \\
(1.28)\end{array}$ & $\begin{array}{l}0.65 \\
(0.23)\end{array}$ & $\begin{array}{l}1.17 \\
(4.62)\end{array}$ & $\begin{array}{l}-5.00 \\
(3.66)\end{array}$ & $\begin{array}{l}-0.02 \\
(0.69)\end{array}$ \\
\hline & Dorset & $\begin{array}{l}-0.98 \\
(1.33)\end{array}$ & $\begin{array}{l}1.07 \\
(0.56)\end{array}$ & $\begin{array}{l}-0.04^{\mathrm{B}} \\
(0.56)\end{array}$ & $\begin{array}{l}0.19 \\
(0.19)\end{array}$ & $\begin{array}{l}-5.33 \\
(1.81)\end{array}$ & $\begin{array}{l}-5.71 \\
(2.25)\end{array}$ & $\begin{array}{l}1.86 \\
(0.37)\end{array}$ \\
\hline & Merino & $\begin{array}{l}-0.83 \\
(1.52)\end{array}$ & $\begin{array}{l}0.39 \\
(0.91)\end{array}$ & $\begin{array}{l}-0.71^{\mathrm{B}} \\
(0.16)\end{array}$ & $\begin{array}{l}-0.07 \\
(0.19)\end{array}$ & $\begin{array}{l}-2.80 \\
(2.95)\end{array}$ & $1.57(2.14)$ & $\begin{array}{l}0.28 \\
(0.87)\end{array}$ \\
\hline & $\begin{array}{l}\text { White } \\
\text { Suffolk }\end{array}$ & $0.52(1.35)$ & 0.86 & $0.56^{\mathrm{b}}$ & 0.26 & 5.52 & $\begin{array}{l}-5.29 \\
(2.62)\end{array}$ & 0.93 \\
\hline & $P$ & 0.389 & 0.573 & 0.004 & $\begin{array}{l}(0.15) \\
0.355\end{array}$ & 0.431 & $\begin{array}{l}(2.02) \\
0.396\end{array}$ & $\begin{array}{l}(0.29) \\
0.198\end{array}$ \\
\hline \multirow[t]{3}{*}{ Sex } & Ewe & $\begin{array}{l}0.21^{-} \\
(0.82)\end{array}$ & $\begin{array}{l}1.08 \\
(0.57)\end{array}$ & $\begin{array}{l}0.45 \\
(0.67)\end{array}$ & $\begin{array}{l}0.33 \\
(0.13)\end{array}$ & $\begin{array}{l}-4.35 \\
(2.11)\end{array}$ & $\begin{array}{l}-3.38 \\
(1.22)\end{array}$ & $\begin{array}{l}1.15 \\
(0.48)\end{array}$ \\
\hline & Wether & $-1.73^{\mathrm{B}}$ & 0.10 & 0.20 & 0.06 & -3.32 & -3.38 & 0.63 \\
\hline & $P$ & $\begin{array}{l}(1.21) \\
0.044\end{array}$ & $\begin{array}{l}(0.43) \\
0.564\end{array}$ & $\begin{array}{l}(0.48) \\
0.063\end{array}$ & $\begin{array}{l}(0.14) \\
0.217\end{array}$ & $\begin{array}{l}(1.44) \\
0.967\end{array}$ & $\begin{array}{l}(2.36) \\
0.985\end{array}$ & $\begin{array}{l}(0.39) \\
0.658\end{array}$ \\
\hline \multirow[t]{3}{*}{ Basal diet } & Pasture-fed & $\begin{array}{l}-4.39^{\mathrm{B}} \\
(0.80)\end{array}$ & $\begin{array}{l}0.60 \\
(0.67)\end{array}$ & $\begin{array}{l}0.76 \\
(0.73)\end{array}$ & $\begin{array}{l}0.30 \\
(0.17)\end{array}$ & $\begin{array}{l}-4.48 \\
(2.43)\end{array}$ & $\begin{array}{l}-3.96 \\
(1.62)\end{array}$ & $\begin{array}{l}1.24 \\
(0.56)\end{array}$ \\
\hline & Lucerne Hay & $2.88^{\mathrm{A}^{\prime}}$ & $\begin{array}{l}0.58 \\
(028)\end{array}$ & -0.11 & 0.08 & -3.20 & -2.79 & 0.55 \\
\hline & $P$ & $\begin{array}{l}(0.65) \\
0.001\end{array}$ & $\begin{array}{l}(0.28) \\
0.381\end{array}$ & $\begin{array}{l}(0.35) \\
0.827\end{array}$ & $\begin{array}{l}(0.08) \\
0.663\end{array}$ & $\begin{array}{l}(0.76) \\
0.333\end{array}$ & $\begin{array}{l}(2.10) \\
0.867\end{array}$ & $\begin{array}{l}(0.26) \\
0.069\end{array}$ \\
\hline
\end{tabular}

A,B,C, within the same column and for a fixed effect, means bearing different superscripts differ significantly $(P<0.05)$. Clean fleece weight (CFW), Mean fibre diameter (FD), coefficient of fibre diameter variation (CV), fibre diameter standard deviation (SD), comfort factor (CF), fibre curvature (CURV), spinning fineness (SF).

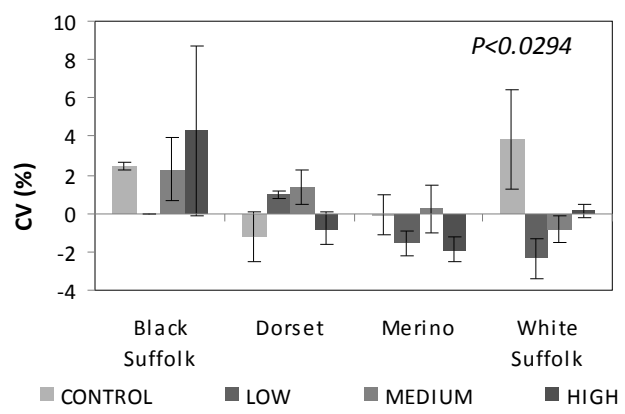

Figure 1. Effect of Spirulina supplementation level and sire breed interaction on fibre diameter coefficient of fibre variation $(\mathrm{CV})$ 


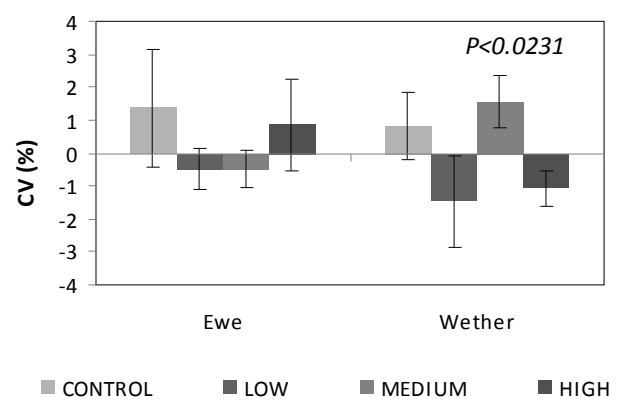

Figure 2. Effect of Spirulina supplementation level and sex interaction on fibre diameter coefficient of fibre variation $(\mathrm{CV})$
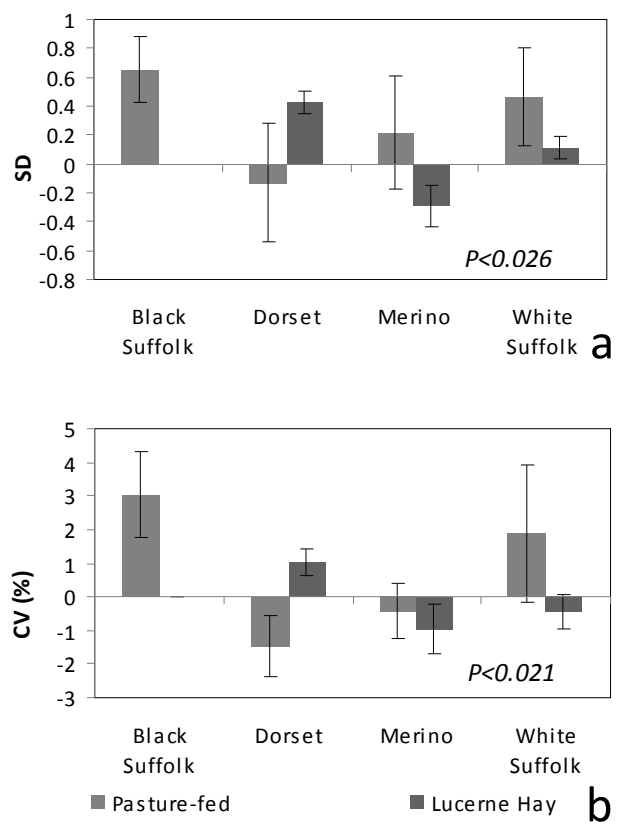

Figure 3. Effect of Spirulina supplementation level and sire breed interaction on fibre diameter standard deviation (SD) and coefficient of fibre variation (CV)

In terms of sex and supplementation level interactions, pasture-fed ewe lambs supplemented on LOW level of Spirulina supplementation had lower SD than CONTROL lambs (Figure 4a). On the other hand, CONTROL pasture-fed ewe had higher CV than lambs supplemented at both LOW and MEDIUM Spirulina levels. Pasture-fed wethers and ewes fed Lucerne hay basal diets had lower CV at high Spirulina supplementation level than other lambs on MEDIUM supplementation (Figure $4 b$ ).

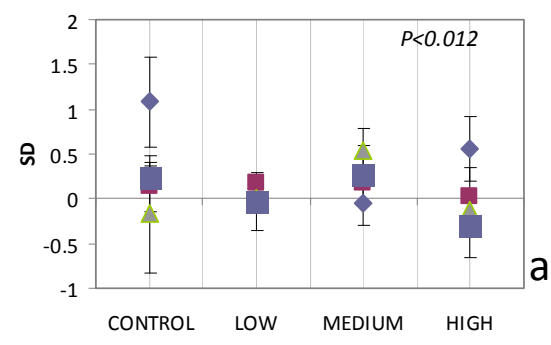




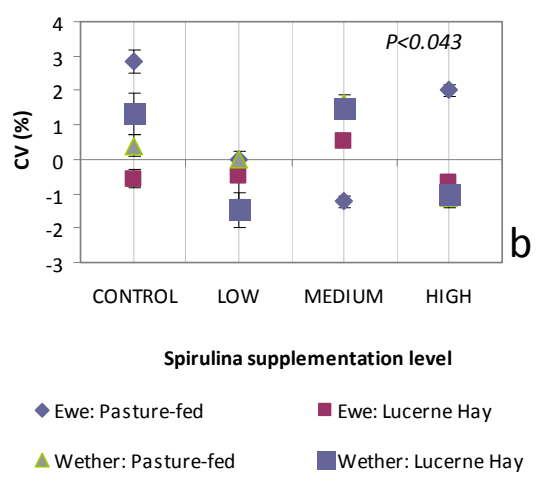

Figure 4. Effect of Spirulina supplementation level, sex and basal diet interaction on fibre diameter standard deviation (SD) and coefficient of fibre variation $(\mathrm{CV})$

\section{Discussion}

From the early review of Spirulina's potential use as an animal feed by Belay et al. (1996) to the current updated literature on its use as a livestock supplement (Holman \& Malau-Aduli, 2012b), there is no published information on the influence of Spirulina supplementation on the wool quality of genetically divergent prime lambs. Therefore, to fill this knowledge gap, this study tested the hypothesis that Spirulina supplementation will improve wool yield without compromising wool quality in dual-purpose prime lambs.

CFW refers to the fibrous content of wool and attracts high price premiums (Holman \& Malau-Aduli, 2012a; Mortimer, Atkins, Semple, \& Fogarty, 2010). Wool fibres are primarily composed of proteins (Plowman, 2003), hence it is possible that with increasing supplementation levels of protein-rich Spirulina, there was a corresponding increase in nutrient partitioning towards wool fibre synthesis, hence the observed increase in CFW. This is in tandem with published literature demonstrating direct correlated response of wool CFW to increased dietary protein (Friend \& Robards, 2005).

Wool synthesis is limited by the availability of sulphur amino acids - cysteine and methionine which are known to increase wool fineness due to low FD (Hynd \& Masters, 2002; Liu \& Masters, 2003). However, Spirulina is low in sulphur amino acid content compared to other protein-rich supplements (Ciferri \& Tiboni, 1985; Volkmann, Imianovsky, Oliveira, \& Sant'Anna, 2008). This low S-amino acid content could have been a contributing factor to FD remaining unchanged with increase in Spirulina supplementation observed in this study. This suggests that protein sourced from Spirulina and partitioned towards wool fibre synthesis promotes fibre growth rate and yield without tampering with fibre diameter. Habib et al. (2001) reported that CFW increased with dietary protein levels while FD remained unchanged.

The variation in CFW due to differences in basal diet could have three possible explanations; 1) The efficiency of feed conversion to wool increased with decreased feed levels (Naqvi \& Rai, 1990) due to changes in energy partitioning; 2) Differences between typical and simulated-drought basal diets in protein degradability and sulphur amino acid content have been identified as two predominant causal factors of CFW differences between diets (White, Young, Phillips, \& Rodehutscord, 2000); and 3) simulated-drought lambs were not exposed to wool contaminants such as dust and vegetable matter typical of pasture fed lambs which are known to decrease CFW, (Holman \& Malau-Aduli, 2012a). Sheep sheltered from wool contaminants using jackets, have previously been shown to have improved CFW (Hatcher, Atkins, \& Thornberry, 2008).

Entire fleece fibre diameter variation is measured objectively using either SD or CV, with CV being a refinement of SD (Holman \& Malau-Aduli, 2012a). While low SD and high CV fleece fibre diameter is preferable, there is currently little or no price incentive (Holman \& Malau-Aduli, 2012a). The significant interactions between sire breed and supplementation level on SD and CV is thought to arise from the strong influence of the genetic make-up of lambs on nutrient partitioning pathways towards wool synthesis (Li, Oddy, \& Nolan, 2008; Scales, Bray, Baird, O'Connell, \& Knight, 2000). Genetic potential varies with lamb sire breed and sex; and have been shown to interact with lambs' diet to affect wool synthesis and wool quality traits (Malau-Aduli \& Akuoch, 2012; Malau-Aduli, Holman, \& Lane, 2012; Pitchford, 1992; Scales et al., 2000). Nevertheless, only SD and CV in White Suffolk-sired lambs and wethers were affected by these variations. Therefore, it is most likely that the 
common Merino maternal genetics of all the lambs used in this study 'standardised' any changes in wool traits over the entire feeding trial period.

In conclusion, dual-purpose and prime lamb operations can benefit from our main finding that clean fleece yields is improved with Spirulina supplementation without compromising other wool quality traits such as fibre diameter, wool comfort factor and spinning fineness. Furthermore, the observed interaction effects of basal diet, sire breed and sex with Spirulina supplementation levels permit flexibility in operational options of optimising profitability from wool in the prime lamb industry. Further research to give a greater understanding of internal nutrient partitioning pathways and controlling factors of Spirulina supplementation effects on lamb growth and liveweight is needed due to their major contribution to profitability in dual-purpose prime lamb operations.

\section{Acknowledgments}

This study was funded with postgraduate research scholarships from the Australian Wool Education Trust (AWET) and The University of Tasmania (UTAS). We appreciate the assistance of Chris Gunn, Barrie Wells, Loudella Deladerriere, John Otto and Will Bignell during the sheep breeding and feed trials.

\section{References}

ABARE. (2012). Agricultural commodieties: June quarter 2012 Australian Bureau of Agricultural and Resource Economics and Sciences (Vol. 2). Canberra (Australia).

Baxter, B. P., \& Cottle, D. J. (1998). The use of midside fleece fibre diameter distribution measurements in sheep selection. Wool Technology and Sheep Breeding, 46(2), 154-171.

Belay, A., Kato, T., \& Ota, Y. (1996). Spirulina (Arthrospira): Potential application as an animal feed supplement. Journal of Applied Phycology, 8(4-5), 303-311.

Ciferri, O., \& Tiboni, O. (1985). The biochemical and industrial potential of Spirulina. Annual Review of Microbiology, 39, 503-526.

Friend, M. A., \& Robards, G. E. (2005). Fibre diameter and staple strength of sheep selected for divergent clean fleece weight when subjected to an increase in intake or diet change. Australian Journal of Agricultural Research, 56(2), 195-201. http://dx.doi.org/10.1071/ar04134

Garnsworthy, P. C., \& Unal, Y. (2004). Estimation of dry-matter intake and digestibility in group-fed dairy cows using near infrared reflectance spectroscopy. Animal Science, 79(2), 327-334.

Habib, G., Siddiqui, M. M., Mian, F. H., Jabbar, J., \& Khan, F. (2001). Effect of protein supplements of varying degradability on growth rate, wool yield and wool quality in grazing lambs. Small Ruminant Research, 41(3), 247-256. http://dx.doi.org/10.1016/S0921-4488(01)00219-X

Harle, K. J., Howden, S. M., Hunt, L. P., \& Dunlop, M. (2007). The potential impact of climate change on the Australian wool industry by 2030. Agricultural Systems, 93(1-3), 61-89. http://dx.doi.org/10.1016/j.agsy.2006.04.003

Hatcher, S., Atkins, K. D., \& Thornberry, K. J. (2008). Strategic use of sheep coats can improve your economic return. Australian Journal of Experimental Agriculture, 48(7), 762-767. http://dx.doi.org/10.1071/EA08036

Holman, B. W. B., Kashani, A., \& Malau-Aduli, A. E. O. (2012). Growth and body conformation responses of genetically divergent Australian sheep to Spirulina (Arthrospira platensis) supplementation. American Journal of Experimental Agriculture, 2(2), 160-173.

Holman, B. W. B., \& Malau-Aduli, A. E. O. (2012a). A review of sheep wool quality traits. Annual Review and Research in Biology, 2(1), 1-14.

Holman, B. W. B., \& Malau-Aduli, A. E. O. (2012b). Spirulina as a livestock supplement and animal feed. Journal of Animal Physiology and Animal Nutrition, 975-623. http://dx.doi.org/10.1111/j.1439-0396.2012.01328.x

Hume, D. A., Whitelaw, C. B. A., \& Archibald, A. L. (2011). The future of animal production: improving productivity and sustainability. Journal of Agricultural Science, 149, 9-16. http://dx.doi.org/10.1017/s0021859610001188

Hynd, P. I., \& Masters, D. G. (2002). Nutrition and wool growth. In M. Freer \& H. Dove (Eds.), Sheep Nutrition (pp. 165-188). Wallingford, Oxon, UK ; New York, NY: CABI Publishing, CSIRO Publishing. 
Li, L., Oddy, V. H., \& Nolan, J. V. (2008). Whole-body protein metabolism and energy expenditure in sheep selected for divergent wool production when fed above or below maintenance. Australian Journal of Experimental Agriculture, 48(5), 657-665. http://dx.doi.org/10.1071/EA07231

Liu, S. M., \& Masters, D. G. (2003). Animo acids utilization for wool production. In J. P. F. D'Mello (Ed.), Amino acids in animal nutrition (2nd ed., pp. 309-328). Willingford, Oxon, UK ; Cambridge, MA, USA: CABI Publishing.

Malau-Aduli, A. E. O., \& Akuoch, J. D. D. (2012). Sire genetics, protein supplementation and gender effects on wool comfort factor in Australian crossbred sheep. American Journal of Experimental Agriculture, 2, 31-46.

Malau-Aduli, A. E. O., Holman, B. W. B., \& Lane, P. (2012). Influence of sire breed, protein supplementation and gender on wool spinning fineness in first-cross Merino lambs. [Refereed Conference Paper]. World Academy of Science, Engineering and Technology Scientia Special Journal, 0067, 1029-1036.

Masters, D. G., Mata, G., \& Liu, S. M. (1999). The influence of type and timing of protein supplementation on wool growth and protein synthesis in the skin of young Merino sheep. Australian Journal of Agricultural Research, 50(4), 497-502. http://dx.doi.org/10.1071/A98190

Mortimer, S. I., Atkins, K. D., Semple, S. J., \& Fogarty, N. M. (2010). Predicted responses in Merino sheep from selection combining visually assessed and measured traits. Animal Production Science, 50(10), 976-982. http://dx.doi.org/10.1071/AN10085

Naqvi, S. M. K., \& Rai, A. K. (1990). Effect of nutritional stress on wool yield, characteristics and efficiency of feed conversion to wool. Livestock Research for Rural Development, 2(2), 61-66.

Nardone, A., Ronchi, B., Lacetera, N., Ranieri, M. S., \& Bernabucci, U. (2010). Effects of climate changes on animal production and sustainability of livestock systems. Livestock Science, 130(1-3), 57-69. http://dx.doi.org/10.1016/j.livsci.2010.02.011

Pitchford, W. (1992). Effect of crossbreeding on components of Hogget wool production. Australian Journal of Agricultural Research, 43(6), 1417-1427. http://dx.doi.org/10.1071/AR9921417

Plowman, J. E. (2003). Proteomic database of wool components. Journal of Chromatography B-Analytical Technologies in the Biomedical and Life Sciences, 787(1), 63-76. http://dx.doi.org/10.1016/s1570-0232(02)00211-8

Scales, G. H., Bray, A. R., Baird, D. B., O'Connell, D., \& Knight, T. L. (2000). Effect of sire breed on growth, carcass, and wool characteristics of lambs born to Merino ewes in New Zealand. New Zealand Journal of Agricultural Research, 43(1), 93-100.

van Soest, P. J., Roberts, J. B., \& Lewis, B. A. (1991). Methods for dietary fiber, neutral detergent fiber, and non-starch polysaccharides in relation to animal nutrition. Journal of Dairy Science, 74(10), 3583-3597.

Volkmann, H., Imianovsky, U., Oliveira, J. L. B., \& Sant'Anna, E. S. (2008). Cultivation of Arthrospira (Spirulina) platensis in desalinator wastewater and salinated synthetic medium: protein content and amino-acid profile. Brazillian Journal of Microbiology, 39(1), 98-101.

White, C. L., Young, P., Phillips, N., \& Rodehutscord, M. (2000). The effect of dietary protein source and protected methionine (Lactet) on wool growth and microbial protein synthesis in Merino wethers. Australian Journal of Agricultural Research, 51(2), 173-184. http://dx.doi.org/10.1071/AR99093

\section{Copyrights}

Copyright for this article is retained by the author(s), with first publication rights granted to the journal.

This is an open-access article distributed under the terms and conditions of the Creative Commons Attribution license (http://creativecommons.org/licenses/by/3.0/). 